\title{
A Rare Variant of Braf Negative Melanoma Originating from Nipple with Comparison of the Literature Data: Case Report
}

\author{
Meme Ucundan Köken Alan \\ Nadir Bir Braf Negatif Melanom Variyantı ve \\ Literatür Bilgisi ile Karşılaştırılması
}

\author{
Nilay DUMAN, ${ }^{a}$ \\ Gül ERKIN, ${ }^{b}$ \\ Özay GÖKÖZ,c \\ Aycan Uğur KAYIKÇIOĞLU, ${ }^{d}$ \\ İsmail ÇELIKK \\ aDepartment of Dermatology, \\ Afyon Kocatepe University \\ Faculty of Medicine, Afyonkarahisar, \\ Departments of \\ ${ }^{b}$ Dermatology, \\ 'Pathology, \\ 'Plastic and Reconstructive Surgery, \\ ePreventive Oncology, \\ Hacettepe University \\ Faculty of Medicine, Ankara
}

Geliş Tarihi/Received: 27.10 .2014

Kabul Tarihi/Accepted: 24.02.2015

Yazışma Adresi/Correspondence:

Nilay DUMAN

Afyon Kocatepe University

Faculty of Medicine,

Department of Dermatology,

Afyonkarahisar,

TÜRKIYE/TURKEY

nilybayram@ hotmail.com

doi: 10.5336/dermato.2014-42208

Copyright (C 2015 by Türkiye Klinikleri

\begin{abstract}
A melanoma originating from the nipple is quite rare. Clinicopathological features of nipple melanoma are not well-known. Furthermore there are no literature data about its molecular pathogenesis. Our aim was to present a nipple melanoma case and to compare it with the previous cases in the literature. Histopathological examination of the ulcerated lesion, which was present on the nipple of a 45 year-old female for 6 months, revealed melanoma with $11 \mathrm{~mm}$ Breslow thickness. Sentinel and regional lymph node metastases were detected and in the follow up, distant metastases developed despite adjuvant interferon therapy. BRAF exon 15 V600E mutation analysis was negative. In conclusion, molecular pathogenesis of the nipple melanoma, which may take an agressive clinical course, needs to be further studied.
\end{abstract}

Key Words: Melanoma; breast

ÖZET Meme ucundan köken alan melanom oldukça nadirdir. Meme ucu melanomunun klinikopatolojik özellikleri çok iyi bilinmemektedir. Ayrıca, moleküler patogenezine dair literatür bilgisi bulunmamaktadır. Buradaki amacımız meme ucunda melanomu bulunan hastayı sunmak ve literatürdeki diğer vakalarla karşılaştırmaktı. Kırkbeş yaşında kadın hastanın 6 aydır meme ucunda mevcut olan ülsere lezyonun histopatolojik incelemesinde $11 \mathrm{~mm}$ Breslow kalınlığına sahip melanom tespit edildi. Sentinel ve bölgesel lenf nodunda metastazı görüldü ve takipte adjuvan interferon tedavisine rağmen uzak metastaz gelişti. BRAF exon 15 V600E mutasyon analizi negatif idi. Sonuç olarak agresif seyre sahip olabilen meme ucu melanomunun moleküler patogenezine dair daha ileri çalışmalara ihtiyaç vardır.

Anahtar Kelimeler: Melanom; meme

Turkiye Klinikleri J Dermatol 2015;25(1):20-3

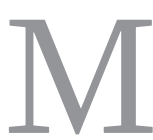
elanoma of the breast has been estimated to be less than $5 \%$ of all melanomas. ${ }^{1}$ Very few cases have been described to date in the areolar area. Primary melanomas arising from the nipple are even rarer, with only few reports are present in the literature. ${ }^{2}$ The clinicopathological features and underlying molecular events of these melanomas are not known well. Herein, we report a case of primary cutaneous melanoma of the nipple in a 45-year-old woman and discuss the clinicopathological features and treatment outcomes compared with the previous reports to date. 


\section{CASE REPORT}

A 45-year-old female presented with a painless, ulcerated tumor existing for 6 months on the nipple of the right breast. She did not have a personal and/or familial history of melanoma. She had skin phototype II and had a history of 35 years intermitant sun exposure. There was not a history of a trauma or melanocytic nevus preexisting the lesion. Her medical history was unremarkable except for allergic asthma. Dermatological examination revealed a 1,5x0,5 cm sharply defined black pigmented firm tumor on the right nipple with superficial ulcerations and a yellow crust (Figure $1)$.

A total excision of the lesion was performed in July 2010. As the frozen biopsy revealed melanoma, the patient underwent a right modified radical mastectomy followed by subsequent sentinel lympadenectomy and right axillary lymph node dissection. Microscopic examination revealed a large melanoma with Breslow thickness of $11 \mathrm{~mm}$ with superficial ulceration (Figure 2). The Clark level was IV. Nests were composed of mostly epitheloid type melanocytes with brownblack pigments in their cytoplasm (Figures 3, 4). Mitotic index was $1 / \mathrm{mm}^{2}$. Lymphohistiocytic infiltration and regression were absent whereas perineural invasion was detected. The resection

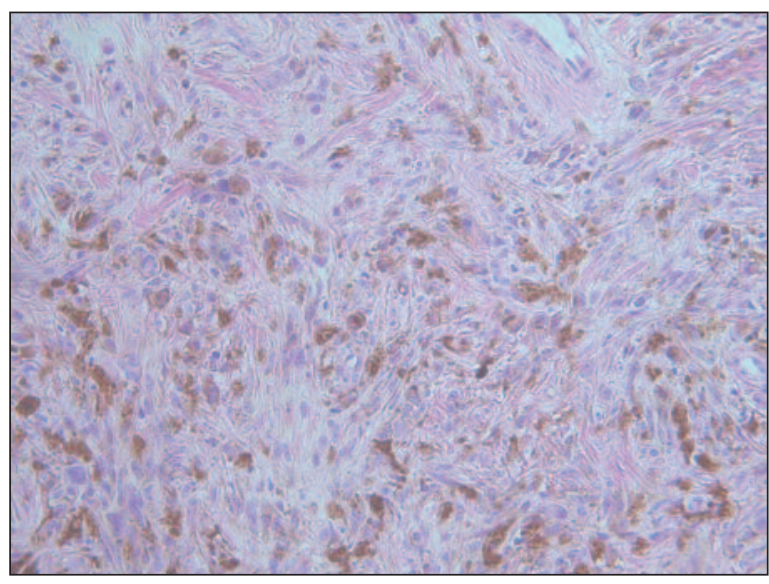

FIGURE 3: A melanoma composed of mostly epitheloid type melanocytes (HE 10x10).

(See color figure at http://www.turkiyeklinikleri.com/journal/dermatoloji-dergisi/1300-0330/)

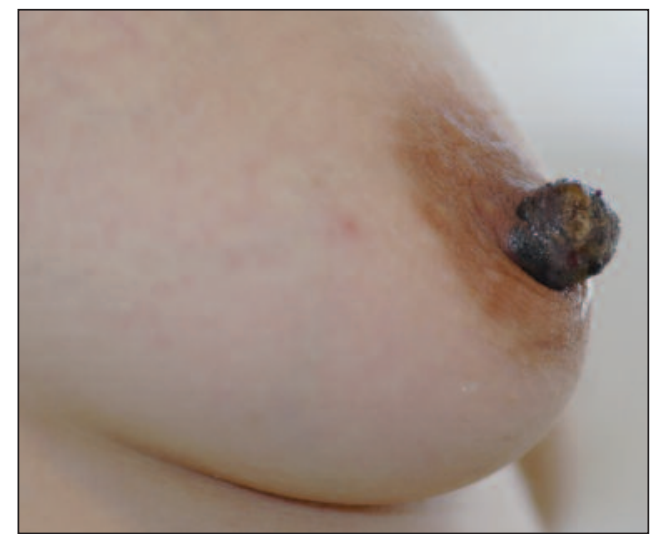

FIGURE 1: A sharply defined black pigmented firm tumor on the nipple with superficial ulcerations and a yellow crust.

(See color figure at http://www.turkiyeklinikleri.com/journal/dermatoloji-dergisi/1300-0330/)

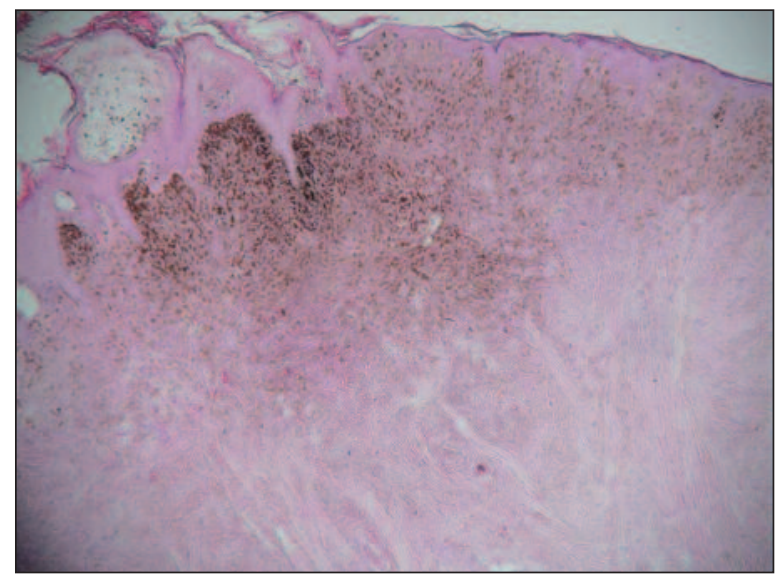

FIGURE 2: A large, heavily pigmented tumor involving the whole dermis, composed of melanocytes (HE $4 \times 10$ ).

(See color figure at $h$ ttp://www.turkiyeklinikleri.com/journal/dermatoloji-dergisi/1300-0330/)

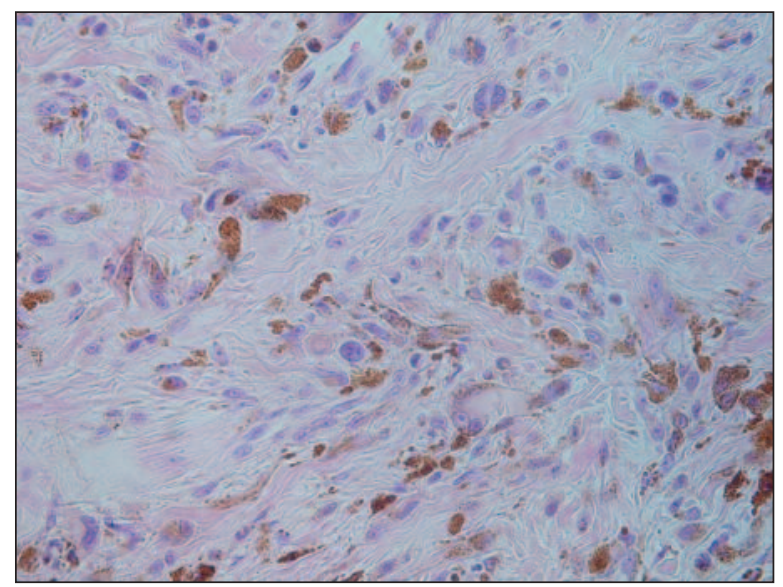

FIGURE 4: Pleomorphic melanocytes with prominent eosinophilic nucleoli (HE 40x10).

(See color figure at http://www.turkiyeklinikleri.com/journal/dermatoloji-dergisi/1300-0330/) 
margins were free of tumor cells, however melanoma metastases was detected in the sentinel lymph node and in 1 of the 35 axillary lymph nodes. The biggest metastatic lymph node was $1,2 \mathrm{~cm}$ and totally involved with metastatic melanoma cells. Positron emission tomography scanning did not reveal any residue or metastatic lesions. The clinical stage of the melanoma was Stage III (T4b N3 M0) and the patological stage was Stage IIIC (T4b N3 MO) according to the 2009 American Joint Cancer Committee melanoma staging system. ${ }^{3}$ Adjuvant interferon therapy (induction phase: $20 \mathrm{mu} / \mathrm{m}^{2}$ intravenously 5 days/week for 4 weeks, maintenance phase: $10 \mathrm{mu} / \mathrm{m}^{2}$ subcutaneously 3 days/week, for 1 year) was initiated. Due to the development of multiple lung, subcutaneous and cervical bone metastases after 2 years of remission, treatment with chemotherapeutic combinations were started. BRAF exon 15 V600E mutation analysis was negative. In the follow up, despite chemotherapy, the metastases progressed and the patient died 4 years after surgery.

\section{DISCUSSION}

The nipple is an unusual site of cutaneous de novo melanoma. In a few reported cases, mammary Paget disease was most strongly considered in the clinical and histopathological differential diagnosis. ${ }^{2}$ It was not difficult to suggest melanoma in the histopathological examination of our case because of the dense pigment within the tumor. However as far as the location is concerned, melanoma is hardly included in the differential diagnosis of nipple tumors.

\begin{tabular}{|c|c|c|c|c|c|c|c|}
\hline \multirow{12}{*}{ 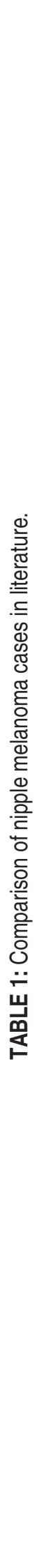 } & 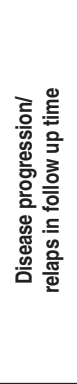 & 2 & 은 & 운 & 2 & 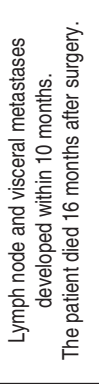 & 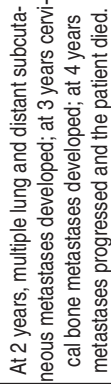 \\
\hline & 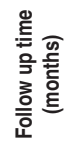 & 8 & 8 & 0 & $\stackrel{ㅇ}{\leftarrow}$ & 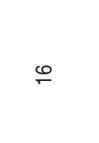 & $\mathscr{y}$ \\
\hline & 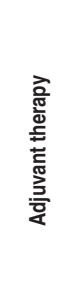 & $\frac{\mathfrak{M}}{z}$ & 울 & 운 & 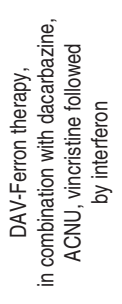 & 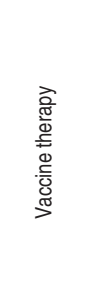 & 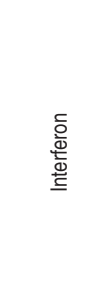 \\
\hline & 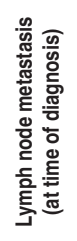 & ' & ' & $\frac{\Upsilon}{z}$ & 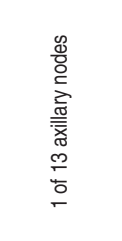 & $\frac{\mathfrak{c}}{z}$ & 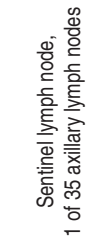 \\
\hline & 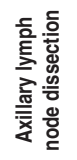 & + & + & . & + & ' & + \\
\hline & 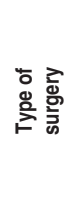 & 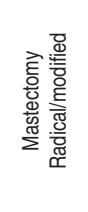 & 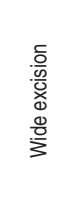 & 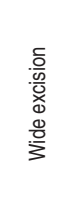 & 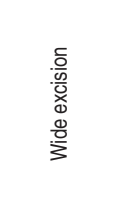 & 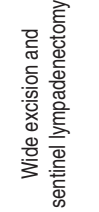 & 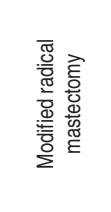 \\
\hline & 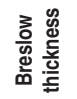 & $\frac{\mathfrak{m}}{z}$ & $\frac{⿱}{2}$ & $\frac{\mathfrak{c}}{z}$ & $\begin{array}{l}\text { E్ } \\
\text { E }\end{array}$ & $\frac{\mathfrak{c}}{2}$ & $\begin{array}{l}\underline{\underline{E}} \\
\bar{\digamma}\end{array}$ \\
\hline & 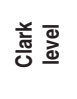 & 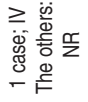 & $\geq$ & $\frac{\Upsilon}{z}$ & $\frac{m}{z}$ & $\geq$ & $\geq$ \\
\hline & 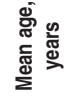 & $\frac{\mathfrak{m}}{z}$ & กิ & 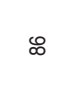 & F & f & ட̊ \\
\hline & 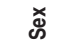 & $\pi \frac{\pi}{4} \frac{\pi}{2}$ & ч & ч & 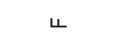 & ч & ч \\
\hline & 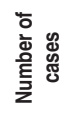 & $\sigma$ & - & - & - & - & - \\
\hline & 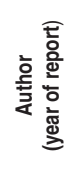 & 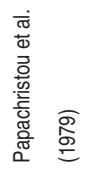 & 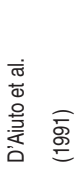 & 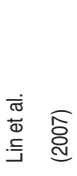 & 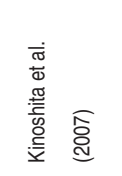 & 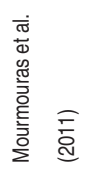 & 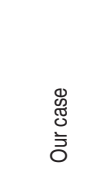 \\
\hline
\end{tabular}

Turkiye Klinikleri J Dermatol 2015;25(1) 
Because of the rare occurrence of nipple melanomas, the clinicopathological and prognostic features are not clearly defined. Furthermore there is a lack of treatment protocols or guidelines for surgical procedures which in turn have an impact on the prognosis. In the previous reports, mastectomy or a wide excision was the choice of therapy. ${ }^{2}$ D'Aiuto et al. applied a wide excision and an axillary lymph node dissection for their case with Clark Level IV nipple melanoma and the patient was still free of disease after 5 years. ${ }^{4}$ On the other hand, Mourmouras et al. reported a case with Clark level IV nipple melanoma who underwent a wide excision and sentinel lympadenectomy without an axillary lymph node dissection and died 16 months after surgery because of the visceral and lymph node metastases despite adjuvant vaccine therapy. ${ }^{2}$ Modified mastectomy and an axillary lymph node dissection were applied, and adjuvant interferon therapy was given to our patient with stage III melanoma, however within 3 years, distant visceral, subcutaneous, and bone metastases had developed. Previous studies with more favorable outcomes did not report the detailed features of other prognostic factors such as the sentinel lymph node status, ulceration, mitotic index, and Breslow thickness and stages, which make it difficult to compare the results with our case. A comparison to available data in the literature was given in Table $1 .^{2,4-7}$
The poor prognosis in our patient might be due to the poor prognostic factors such as presence of ulceration, Breslow thickness of $11 \mathrm{~mm}$, sentinel and regional lymph node metastasis, presence of perineural invasion and mitotic index as $1 / \mathrm{mm}^{2} .8,9$ Although the location of melanoma is not currently considered as a prognostic factor, the nipple region can easily be neglected during routine physical examination, and it has a delicate lymphatic circulation, which could impair the prognosis when seen as a rapid thickening of the melanoma within a short time period, as in our case..$^{8,9}$

In the previous reports, there is no data about the molecular analysis of the nipple melanomas. We found BRAF exon 15 V600E mutation to be negative in our case. Approximately $40-60 \%$ of cutaneous melanomas carry mutations in the BRAF gene, and about $90 \%$ of these mutations are found to be V600E. ${ }^{10}$ The molecular etiopathogenesis of nipple melanoma might be excluding the BRAF pathway which needs to be clarified in future studies.

In conclusion, primary cutaneous melanoma can arise from the nipple. Nipple melanoma can thicken within a short time period and can take an aggressive course. The role of nipple location on prognosis needs to be clarified. The molecular etiopathogenesis including other mutations and optimal treatment modalities needs to be further clarified in this particular variant of melanoma.

\section{REFERENCES}

1. Kurul S, Taş F, Büyükbabani N, Mudun A, Baykal C, Camlica H. Different manifestations of malignant melanoma in the breast: a report of 12 cases and a review of the literature. Jpn $\mathrm{J}$ Clin Oncol 2005;35(4):202-6.

2. Mourmouras V, Ambrosio MR, Onorati M, Rocca BJ, Di Mari N, De Luca F, et al. Melanoma of the nipple. An additional case. Pathologica 2011;103(1):25-6.

3. Balch CM, Gershenwald JE, Soong SJ, Thompson JF, Atkins MB, Byrd DR, et al. Final version of 2009 AJCC melanoma staging and classification. J Clin Oncol 2009;27(36):6199-206.
4. D’Aiuto G, Del Vecchio S, Mansi L, D'Aprile M, Botti G, Salvatore M. Malignant melanoma of the nipple: a case studied with radiolabeled monoclonal antibody. Tumori 1991;77(5):44951.

5. Papachristou DN, Kinne D, Ashikari R, Fortner JG. Melanoma of the nipple and areola. $\mathrm{Br}$ J Surg 1979;66(4):287-8.

6. Lin CH, Lee HS, Yu JC. Melanoma of the nipple mimicking Paget's disease. Dermatol Online J 2007;13(2):18.

7. Kinoshita S, Yoshimoto K, Kyoda S, Hirano A, Shioya H, Kobayashi S, et al. Malignant melanoma originating on the female nipple: a case report. Breast Cancer 2007;14(1):105-8.

8. Kim SK, Kim YW, Youn HJ, Park HS, Jung $\mathrm{SH}$. Primary cutaneous malignant melanoma of the breast. J Korean Surg Soc 2012;83(6): 388-92.

9. Coit DG, Andtbacka R, Bichakjian CK, Dilawari RA, Dimaio D, Guild V, et al. Melanoma. J Natl Compr Canc Netw 2009;7(3):250-75.

10. Davies H, Bignell GR, Cox C, Stephens P, Edkins S, Clegg S, et al. Mutations of the BRAF gene in human cancer. Nature 2002; 417(6892):949-54. 